\title{
Influence of secretin and caerulein on acid phosphatase activity in human saliva
}

\author{
Marek Marcinkiewicz ${ }^{\S}$, Aneta Dąbrowska ${ }^{\dagger}$ Ewa Czyżewska ${ }^{\S}$, \\ Stanisława Zyta Grabowska ${ }^{\ddagger}$ and Stanisław Kreczko*
}

\author{
Departments of ${ }^{\S}$ Physiology and ${ }^{\dagger}$ Gastroenterology, J. Sniadecki’s Regional Hospital \\ Departments of ${ }^{\ddagger}$ Maxillofacial Surgery and "Pediatric Laboratory Diagnostics, Medical School of Bialystok, Bialystok, Poland
}

(Received 6 May 1998 and accepted 17 February 1999)

\begin{abstract}
Experimental studies have demonstrated a structural and functional correlation between the pancreas and salivary glands. Therefore, one may suppose that caerulein plus secretin, used in functional exploration of the exocrine pancreas, could exert an influence on acid phosphatase activity (AcP) and its isoenzymes (tartrate sensitive-TsAcP, tartrate resistant-TRAP acid phosphatases) in whole saliva in humans. The current study was conducted in 14 asymptomatic volunteers (six woman and eight men, mean age 34 , range $27-45$ ). Salivary secretions were collected under basal conditions (intravenous infusion of $0.15 \mathrm{~mol} \mathrm{l}^{-1} \mathrm{NaCl}$ ) and during intravenous infusion of secretin plus caerulein at different doses. Stimulation with secretin $\left(50 \mathrm{mKE} \mathrm{kg}^{-1} \mathrm{~min}^{-1}\right)$ and caerulein $\left(2.5 \mathrm{ng} \mathrm{kg}^{-1} \mathrm{~min}^{-1}\right)$ resulted in a marked and rapid decrease of salivary flow rate. TRAP activity decreased during the first $20 \mathrm{~min}$ of hormonal infusion $(1.09 \pm 0.19$ $\mathrm{mU} \mathrm{ml}^{-1}$ vs.1.93 $\pm 0.18 \mathrm{mU} \mathrm{ml}^{-1}, 1.16 \pm 0.12 \mathrm{mU} \mathrm{ml}^{-1}$ vs.1.86 $\left.\pm 0.17 \mathrm{mU} \mathrm{ml}^{-1}, \mathrm{p}<0.05\right)$. AcP and TsAcP activity during intravenous infusion of secretin plus caerulein remained unchanged. These results point to a wider than expected participation of the digestive system in hormonal control of biochemical processes taking place inside the oral cavity. (J. Oral Sci. 41, 29-34, 1999)
\end{abstract}

Key words: acid phosphatase; caerulein; secretin; whole saliva.

\section{Introduction}

Experiments carried out on animals show morphologic similarities between the exocrine pancreas and salivary glands (1-4). An assumption that these glands may play similar functions led us to perform a series of studies to examine controversies around hormonal regulatory mechanisms common for both the pancreas and salivary glands. It was shown that gastrointestinal hormones such as secretin and cholecystokinin (CCK), besides their basic function of stimulating the exocrine

Correspondence to Dr. Marek Marcinkiewicz, Medical School, Department of Physiology, Mickiewicza Street 2 c,15-230 Bialystok, Poland. part of the pancreas, also decrease the volume of excreted saliva and modify the concentration of salivary enzymatic proteins (5-8). Thus it is possible that changes in CCK excretion in patients with chronic pancreatitis $(9,10)$ change the course of metabolic processes in saliva that results in disturbance of physicochemical homeostasis in the oral cavity. Therefore disorders of oral mucosa may arise or get intensified and teeth may become more susceptible to caries. Measurement of acid phosphatase (AcP, E.C. 3.1.3.2) activity is a commonly used biochemical index of pathologic processes taking place in the oral cavity. The measurement includes 6 isoenzymes denoted by numbers from 0 to 5 . Tartrate-resistant acid phosphatase (TRAP, isoenzyme 5) is secreted by osteoclasts, macrophages, and placenta (11). The subfraction of acid phosphatase secreted by osteoclasts is denoted as isoenzyme $5 \mathrm{~b}$. This isoenzyme seems to be essential for demineralization of hard tissue in tooth roots and for digestion of bone matrix components (12). It is likely that secretin and CCK modify TRAP activity in the oral cavity thus affecting metabolic processes taking place in tooth tissues. Yet the contribution of gastrointestinal hormones in changes of AcP activity in saliva is not known.

The purpose of this work was to examine the influence of gastrointestinal peptides, secretin and caerulein (pharmacological analogue of CCK) on AcP, TRAP and tartrate sensitive acid phosphatase isoenzyme (TsAcP) activity in whole saliva of healthy subjects.

\section{Materials and Methods}

Examinations were carried out on 14 subjects (mean age 34 yr; range 28-45), eight males and six females, subjectively healthy, non-smokers, without caries or periodontal diseases. Subjects with any earlier organic or functional disorder of the digestive system were excluded from the study.

The subjects did not take any medications for at least 14 days before the examination. Saliva was obtained after overnight fasting and before their teeth were brushed. Directly before the collection of saliva the examined subjects were maintained in a comfortable, semi-recumbent position and they were instructed to abstain from swallowing and other mouth and face movements, and to remain in the state of complete rest for the period of at least five minutes. Whole saliva is a mixture of all glandular secretions into the oral cavity and among others 
it includes bacteria, leukocytes, necrotic epithelial cells, alimentary residue, and fluid from gingival pockets (13). Such saliva was obtained by spiting (14) every $15-30$ seconds during the procedure into a volumetric receptacle (a sialometer, Proflow Incorporated, Amityville, New York) emptied every 10 minutes to storage tubes placed in ice. Subjects were instructed not to swallow during the entire collection period. At-30 min (Table 1, column 1), the experimental procedure was begun and lasted 100 minutes (Table 1). In each subject, on alternate days and in random order, five collection modes were implemented. In each collection mode the following salivary samples were sequentially collected: 1$)$ Trial collectionconsisting of three consecutive 10-min intervals (-30 to $0 \mathrm{~min}$; Table 1, column 1), collected to eliminate the enzyme activity variations due to exogenous sources (non-salivary elements such as food debris, desquamated epithelial cells, and bacteria from oral cavity) and to familiarize the subject with the method. Data from this collection period was excluded from further analysis. 2) Basal saliva collection, during intravenous infusion of $0.15 \mathrm{~mol} \mathrm{l}^{-1} \mathrm{NaCl}$, which represented the resting values of examined parameters (0 to $10 \mathrm{~min}$; Table 1, column 2). 3) Saliva collected during intravenous infusion of $0.15 \mathrm{~mol} \mathrm{l}^{-1} \mathrm{NaCl}$ (control) or secretin (Sekretolin Diagnosticum, Hoechst AG) with caerulein (Takus, Farmitalia, Carlo Erba) (stimulation). The stimulation was implemented in four infusion modes (A, $\mathrm{B}, \mathrm{C}, \mathrm{D})$ on alternate days and in random order at the doses outlined in Table 2. This collection period consisted of four consecutive 10-min intervals ( 10 to $50 \mathrm{~min}$; Table 1 , column 3-6) and followed the basal saliva collection. 4) Saliva collected during intravenous infusion of $0.15 \mathrm{~mol} \mathrm{l}^{-1} \mathrm{NaCl}$ for two consecutive 10-min intervals (50 to $70 \mathrm{~min}$; Table 1 , column 7,8).

The examinations were carried out in the morning (8:0010:00 a.m.) due to the day and night rhythm of saliva secretion. Directly after obtaining each 10-min portion (except of the trial collection rejected from further analysis), the portion was centrifuged (20 minutes at $1500 \mathrm{rpm})$ at the temperature of $40^{\circ} \mathrm{C}$ and the supernatant was separated from the sediment for further processing. Immediately after centrifugation, acid phosphatase activity was determined using the "Biochemtest AcP+AcP-P” (Polish Chemical Reagents, Gliwice) diagnostic kit. The biochemical procedure is based on enzymatic degradation of $p$-nitrophenyl-phosphate to $p$-nitrophenol in acidic milieu. Released $p$-nitrophenol becomes yellow stained anion after changing the environment into alkaline. Intensity of the staining, which is proportional to the enzyme activity, was read on a spectrophotometer at the wave length $405 \mathrm{~nm}$. Some isoenzymes are inhibited by tartrate and this property was utilized to determine activity of particular fractions of AcP. Activity of AcP, TsAcP, and TRAP was expressed in international units $\left(\mathrm{mU} \mathrm{ml}^{-1}\right)$. Salivary protein was monitored by the Lowry methodology as described previously (15). Protein data were calculated as a concentration (expressed in $\mathrm{ml} \mathrm{min}^{-1}$ ). The salivary flow rate was measured volumetrically and expressed in $\mathrm{mg} \mathrm{ml}^{-1}$. Data are presented as mean values and standard errors (S.E.) for each 10-min interval. Statistical analysis was carried out using SPSS Advanced Version and Microsoft Excel v. 7.0A programs. Repeated-measures ANOVA were conducted on paired samples of time course data, and each subject acted as his/her own control. Independentsample t-tests were used for analysis of age and sex influences on AcP and its isoenzymes (TsAcP, TRAP) activity.

The research protocol was approved by the School Senate Commission of the Medical Academy in Bialystok which supervises research using human subjects.

\section{Results}

Under our experimental conditions, all the dosages of caerulein with secretin caused inhibition of salivary flow rate and TRAP activity (Fig. 1), however a statistically significant decrease (p $<0.05$ ) was obtained only with the highest doses (secretin-25 $\mathrm{mKE} \mathrm{kg}{ }^{-1} \mathrm{~min}^{-1}, 50 \mathrm{mKE} \mathrm{kg}{ }^{-1} \min ^{-1}$ and caerulein-1.25 $\mathrm{ng} \mathrm{kg}^{-1}$ $\min ^{-1}, 2.5 \mathrm{ng} \mathrm{kg}^{-1} \mathrm{~min}^{-1}$ ). In the control condition, infusion of saline over a period of $60 \mathrm{~min}$ resulted in a small, non-significant change in salivary volume (from $0.52 \pm 0.04 \mathrm{ml} \mathrm{min}^{-1}$ to 0.55 $\pm 0.04 \mathrm{ml} \mathrm{min}^{-1}$ ), protein concentration (from $1.54 \pm 0.12 \mathrm{mg}$

Table 2 Infusion modes of intravenous administration of secretin plus caerulein

\begin{tabular}{ccc}
\hline Infusion mode & $\begin{array}{c}\text { Dosage of secretin } \\
\left(\mathrm{mKE} \mathrm{kg}^{-1} \mathrm{~min}^{-1}\right)\end{array}$ & $\begin{array}{c}\text { Dosage of caerulein } \\
\left(\mathrm{ng} \mathrm{kg}^{-1} \mathrm{~min}^{-1}\right)\end{array}$ \\
\hline $\mathrm{A}$ & 6.3 & 0.31 \\
$\mathrm{~B}$ & 12.5 & 0.63 \\
$\mathrm{C}$ & 25 & 1.25 \\
$\mathrm{D}$ & 50 & 2.50 \\
\hline
\end{tabular}

Table 1 Saliva collection

\begin{tabular}{|c|c|c|c|c|c|c|c|c|}
\hline Column: & 1 & 2 & 3 & 4 & 5 & 6 & 7 & 8 \\
\hline Collection time (min): & -30 to 0 & 0 to 10 & 10 to 20 & 20 to 30 & 30 to 40 & 40 to 50 & 50 to 60 & 60 to 70 \\
\hline Interval time (min): & 30 & 10 & 10 & 10 & 10 & 10 & 10 & 10 \\
\hline Collection period: & $\begin{array}{c}\text { Trial } \\
\text { collection }\end{array}$ & $\begin{array}{l}\text { Basal } \\
\left(\mathrm{NaCl}^{\mathrm{a}}\right)\end{array}$ & \multicolumn{4}{|c|}{$\begin{array}{c}\text { Control }\left(\mathrm{NaCl}^{a}\right) \text { or Stimulation (Secretin plus } \\
\left.\text { caerulein }^{b}\right)\end{array}$} & \multicolumn{2}{|c|}{$\mathrm{NaCl}^{\mathrm{a}}$} \\
\hline
\end{tabular}

${ }^{\mathrm{a}}$ Intravenous infusion of $0.15 \mathrm{~mol} \mathrm{l}^{-1} \mathrm{NaCl} .{ }^{\mathrm{b}}$ Intravenous infusion of secretin plus caerulein at doses depending on infusion mode (Table 2). 


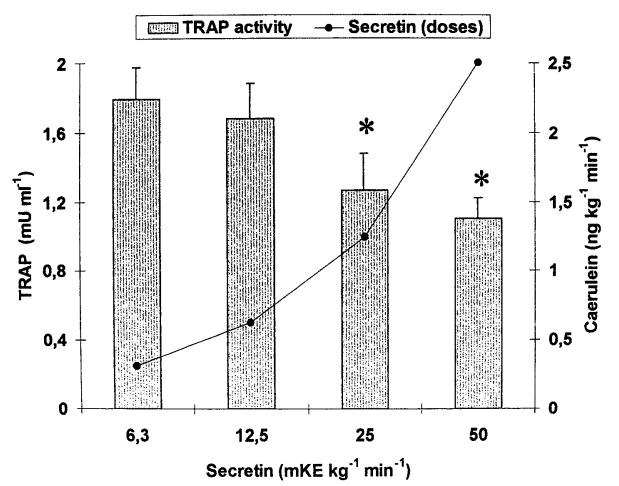

Fig. 1 Dose-response curve of TRAP (tartrate resistant acid phosphatase) activity in whole saliva during the first $20 \mathrm{~min}$ of intravenous infusion of secretin plus caerulein administered at different doses (each value represents mean \pm S.E.). ${ }^{*} p<0.05$ (Secretin plus caerulein vs. Control samples collected during intravenous infusion with 0.15 mol $\left.1^{-1} \mathrm{NaCl}\right) . \mathrm{n}=13$ subjects.

$\mathrm{ml}^{-1}$ to $1.67 \pm 0.13 \mathrm{mg} \mathrm{ml}^{-1}$ ), AcP (from $9.54 \pm 0.76 \mathrm{mU} \mathrm{ml}^{-1}$ to $11.32 \pm 1.17 \mathrm{mU} \mathrm{ml}^{-1}$ ), TsAcP (from $7.8 \pm 0.67 \mathrm{mU} \mathrm{ml}^{-1}$ to 9.40 $\pm 1.00 \mathrm{mU} \mathrm{ml}^{-1}$ ) and TRAP activity (from $1.69 \pm 0.22 \mathrm{mU} \mathrm{ml}^{-}$ ${ }^{1}$ to $1.93 \pm 0.21 \mathrm{mU} \mathrm{ml}^{-1}$ ) (Table 3). Administration of secretin plus caerulein caused a significant decrease $(\mathrm{p}<0.05$ relative to control) in salivary volume from $0.54 \pm 0.04 \mathrm{ml} \mathrm{min}^{-1}$ to 0.34 $\pm 0.04 \mathrm{ml} \mathrm{min}^{-1}$ during the first $10 \mathrm{~min}$, reaching a maximum effect $\left(0.52 \pm 0.04 \mathrm{ml} \mathrm{min}^{-1}\right.$ vs. $0.30 \pm 0.04 \mathrm{ml} \mathrm{min}^{-1}, \mathrm{p}<0.05$ relative to control) after 20 minutes of continuous infusion. This decreased salivary volume was maintained throughout the remaining infusion period and significant differences $(\mathrm{p}<0.05)$ were also reached after $30 \mathrm{~min}\left(0.38 \pm 0.04 \mathrm{ml} \mathrm{min}^{-1}\right.$ vs. 0.55 $\pm 0.04 \mathrm{ml} \mathrm{min}^{-1}, \mathrm{p}<0.05$ relative to control $)$, and $40 \mathrm{~min}(0.38$ $\pm 0.03 \mathrm{ml} \mathrm{min}^{-1}$ vs. $0.54 \pm 0.04 \mathrm{ml} \mathrm{min}^{-1}, \mathrm{p}<0.05$ relative to control) of stimulation. Interestingly, intravenous infusion of secretin plus caerulein resulted in an immediate (the first $10 \mathrm{~min}$ of infusion) decrease of salivary TRAP activity $(1.09 \pm 0.19 \mathrm{mU}$ $\mathrm{ml}^{-1}$ vs. $\left.1.93 \pm 0.18 \mathrm{mU} \mathrm{ml}^{-1}, \mathrm{p}<0.05\right)$. This decrease was sustained only during the next $10 \mathrm{~min}$ of subsequent hormonal infusion $\left(1.16 \pm 0.12 \mathrm{mU} \mathrm{ml}^{-1}\right.$ vs. $\left.1.86 \pm 0.17 \mathrm{mU} \mathrm{ml}^{-1}, \mathrm{p}<0.05\right)$ and than gradually returned to the corresponding control values (Table 4). The salivary protein concentration during hormonal stimulation was similar to the values seen in control conditions (Table 3). Moreover, secretin with caerulein had no statistically significant effect on AcP and TsAcP activity throughout the infusion period (Table 4). Age and sex of the examined subjects did not significantly influence activity of particular AcP fractions (Table 5).

\section{Discussion}

Changes of enzymatic activity during combined stimulation with secretin and caerulein, similar to those in the pancreatic juice, were observed in saliva taken selectively from the parotid gland $(8,16)$. Individual gland secretion is superior to whole saliva for some compositional analyses because whole saliva contains nonsalivary elements such as desquamated epithelial cells, food debris, bacteria, gingival crevicular fluid and leukocytes. However, for assessment of overall salivary protective potential within the oral cavity, whole saliva is superior and more clinically relevant $(17,18)$. Thus we have adopted a model using whole saliva. Peptides used in this study are essential humoral factors which stimulate pancreatic secretion $(6,19)$. Substitution of CCK by caerulein is commonly accepted. Doses of secretin and caerulein correspond to doses used in the stimulation of pancreatic secretion and they agree with data published by other authors using a comparable experimental design (7).

Output of AcP measured in whole human saliva has marked night and day variations (20). They mainly appear after meals when total AcP output decreases by $50-80 \%$ as compared to saliva taken after overnight fasting (20). It is likely that enzymatic changes occurring after meals affect not only AcP output but also its isoenzymes: TsAcP and TRAP. In view of our examinations, these changes of AcP output may be due

Table 3 Salivary flow rate and protein concentration during intravenous infusion of $0.15 \mathrm{~mol} \mathrm{l}^{-1} \mathrm{NaCl}$ (control) as well as secretin $50 \mathrm{mKE} \mathrm{kg} \mathrm{min}^{-1}$ plus caerulein $2.5 \mathrm{ng} \mathrm{kg}^{-1} \mathrm{~min}^{-1}$ (stimulation)

\begin{tabular}{|c|c|c|c|c|c|c|c|}
\hline \multirow[b]{3}{*}{ Parameter } & \multicolumn{7}{|c|}{ Time (min) } \\
\hline & $0-10$ & $10-20$ & $20-30$ & $30-40$ & $40-50$ & $50-60$ & $60-70$ \\
\hline & Basal $(\mathrm{NaCl})$ & \multicolumn{4}{|c|}{ Control $(\mathrm{NaCl})$ or Stimulation (Secretin plus Caerulein) } & $\mathrm{NaCl}$ & $\mathrm{NaCl}$ \\
\hline \multicolumn{8}{|l|}{ Salivary flow rate $\left(\mathrm{ml} \mathrm{min}^{-1}\right)$} \\
\hline control & $0.55 \pm 0.04$ & $0.53 \pm 0.05$ & $0.52 \pm 0.04$ & $0.55 \pm 0.04$ & $0.54 \pm 0.04$ & $0.53 \pm 0.03$ & $0.54 \pm 0.03$ \\
\hline stimulation & $0.54 \pm 0.04$ & $0.34 \pm 0.04^{*}$ & $0.30 \pm 0.04^{*}$ & $0.38 \pm 0.04^{\circ}$ & $0.38 \pm 0.03^{*}$ & $0.50 \pm 0.04$ & $0.54 \pm 0.04$ \\
\hline \multicolumn{8}{|c|}{ Protein concentration $\left(\mathrm{mg} \mathrm{ml}^{-1}\right)$} \\
\hline control & $1.54 \pm 0.12$ & $1.67 \pm 0.13$ & $1.64 \pm 0.14$ & $1.55 \pm 0.15$ & $1.63 \pm 0.17$ & $1.64 \pm 0.15$ & $1.59 \pm 0.19$ \\
\hline stimulation & $1.72 \pm 0.2$ & $1.93 \pm 0.12$ & $1.66 \pm 0.11$ & $1.70 \pm 0.12$ & $1.68 \pm 0.19$ & $1.66 \pm 0.10$ & $1.59 \pm 0.10$ \\
\hline
\end{tabular}

Values are means $\pm \mathrm{SE} .{ }^{\circ} \mathrm{p}<0.05$ - a difference between groups (control vs. stimulation) at this same time point 
Table 4 Acid phosphatase (AcP) and its isoenzymes (tartrate sensitive-TsAcP, and tartrate resistantTRAP) activity during intravenous infusion of $0.15 \mathrm{~mol}^{-1} \mathrm{NaCl}$ (Control) and secretin 50 $\mathrm{mKE} \mathrm{kg}^{-1} \mathrm{~min}^{-1}$ plus caeruein $2.5 \mathrm{ng} \mathrm{kg}^{-1} \min ^{-1}$ (Stimulation)

\begin{tabular}{|c|c|c|c|c|c|c|c|}
\hline \multirow[b]{3}{*}{ Parameter } & \multicolumn{7}{|c|}{ Time (min) } \\
\hline & $0-10$ & $10-20$ & $20-30$ & $30-40$ & $40-50$ & $50-60$ & $60-70$ \\
\hline & Basal ( $\mathrm{NaCl})$ & \multicolumn{4}{|c|}{ Control ( $\mathrm{NaCl}$ ) or Stimulation (Secretin plus Caerulein) } & $\mathrm{NaCl}$ & $\mathrm{NaCl}$ \\
\hline \multicolumn{8}{|l|}{ AcP activity $\left(\mathrm{mU} \mathrm{m}^{-1}\right)$} \\
\hline control & $10.79 \pm 0.92$ & $9.77 \pm 0.68$ & $10.75 \pm 0.90$ & $9.54 \pm 0.76$ & $10.79 \pm 1.17$ & $11.32 \pm 1.17$ & $9.85 \pm 1.14$ \\
\hline stimulation & $11.44 \pm 1.16$ & $11.04 \pm 1.03$ & $9.73 \pm 0.77$ & $11.20 \pm 1.23$ & $9.55 \pm 1.03$ & $9.38 \pm 0.91$ & $11.50 \pm 1.48$ \\
\hline \multicolumn{8}{|l|}{ TsAcP activity $\left(\mathrm{mU} \mathrm{m}^{-1}\right)$} \\
\hline control & $8.98 \pm 0.84$ & $7.84 \pm 0.62$ & $8.88 \pm 0.78$ & $7.8 \pm 0.67$ & $8.97 \pm 1.05$ & $9.40 \pm 1.00$ & $8.15 \pm 0.98$ \\
\hline stimulation & $9.57 \pm 1.1$ & $9.95 \pm 1.05$ & $8.56 \pm 0.73$ & $9.78 \pm 1.20$ & $7.70 \pm 1.03$ & $7.60 \pm 0.82$ & $9.87 \pm 1.43$ \\
\hline \multicolumn{8}{|l|}{ TRAP activity (mU ml ${ }^{-1}$ ) } \\
\hline control & $1.82 \pm 0.16$ & $1.93 \pm 0.18$ & $1.86 \pm 0.17$ & $1.74 \pm 0.17$ & $1.82 \pm 0.18$ & $1.93 \pm 0.21$ & $1.69 \pm 0.22$ \\
\hline stimulation & $1.87 \pm 0.15$ & $1.09 \pm 0.19^{*}$ & $1.16 \pm 0.12^{*}$ & $1.42 \pm 0.23$ & $1.86 \pm 0.19$ & $1.78 \pm 0.18$ & $1.63 \pm 0.20$ \\
\hline
\end{tabular}

Values are means $\pm \mathrm{SE} .{ }^{*} \mathrm{p}<0.05$ - a difference between groups (control vs. stimulation) at this same time point.

Table 5 Influence of age and sex on salivary parameters during intravenous infusion of $0.15 \mathrm{~mol}^{-1} \mathrm{NaCl}$ (Control) in 14 asymptomatic volunteers

\begin{tabular}{|c|c|c|c|c|}
\hline \multirow[b]{2}{*}{ Subgroup } & \multirow[b]{2}{*}{$\mathrm{N}$} & \multicolumn{3}{|c|}{ Parameters } \\
\hline & & $\begin{array}{l}\text { AcP activity } \\
\left(\mathrm{mU} \mathrm{ml}^{-1}\right)\end{array}$ & $\begin{array}{c}\text { TsAcP activity } \\
\left(\mathrm{mU} \mathrm{ml}^{-1}\right)\end{array}$ & 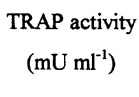 \\
\hline Male & 8 & $11.36 \pm 1.27$ & $9.31 \pm 1.11$ & $2.06 \pm 0.25$ \\
\hline Female & 6 & $8.92 \pm 0.92$ & $7.30 \pm 0.77$ & $1.63 \pm 0.19$ \\
\hline$<34 \mathrm{yr}$ & 7 & $9.61 \pm 1.02$ & $7.73 \pm 0.88$ & $1.89 \pm 0.27$ \\
\hline$>34 \mathrm{yr}$ & 7 & $10.81 \pm 1.13$ & $9.02 \pm 1.00$ & $1.79 \pm 0.16$ \\
\hline
\end{tabular}

$\mathrm{N}$ - number of subjects; AcP - acid phosphatase (total activity); TsAcP - tartrate sensitive acid phosphatase; TRAP - tartrate resistant acid phosphatase. Values are means \pm S.E. To simplify presentation, time-course data observed during control (collection time 10 to $50 \mathrm{~min}$; Table 1, column 3-6) were averaged. Age and sex did not significantly $(\mathrm{p}>0.05)$ influence activity of particular AcP fractions.

not only to passive washing out of some sources of enzymatic activity from the oral cavity, but also may result from the inhibitory influence of gastrointestinal hormones on salivary glands. The proposed influence of gastrointestinal hormones on the output of AcP and its isoenzymes seems to be relevant to the results of examinations presented by Liddle et al. (10) showing an increase of the plasma CCK and secretin levels 15-20 minutes after intake of a fluid meal. The peptides examined in the present study did not significantly affect activity of the quantitatively dominating enzyme TsAcP and thus no significant changes in activity of AcP were observed. This is probably due to the fact that the enzyme TsAcP is synthesized and secreted into saliva mainly by extraglandular sources: e.g., microbes, desquamated epithelium, and undigested food residues which are not directly controlled by hormonal influences. Regulation of TRAP secretion in the salivary system, especially in intercalary duct cells (21), seems to be related to the two types of neurotransmitters and hormonal effects on salivary gland protein synthesis and secretion: 1) activation of receptors which mobilize $\mathrm{Ca}^{2+}$, and activate protein kinase (C kinase); 2) activation of receptors which increase cyclic AMP (cAMP) formation. The first effect is generated by activation of ( $\alpha$-adrenergic and muscariniccholinergic receptors, and mediated through inositol trisphosphate (IP3) and diacylglicerol (DAG) $(22,23)$. ( $\alpha$ Adrenergic and muscarinic-cholinergic receptors mobilize $\mathrm{Ca}^{2+}$ from stores in the endoplasmic reticulum, and $\mathrm{Ca}^{2+}$ dependent steps in mRNA translation are blocked (23). The second effect (mediated by activation of $B$-adrenergic receptors) increases cAMP formation, protein synthesis and secretion (24, 25). After B-adrenergic stimulation there is a rapid increase in cAMP concentration in salivary acinar cells and an activation of a cAMP-dependent protein kinase $(26,27)$. These changes are coupled to intensified exocytosis and increased protein secretion, however a clear mechanism is still unknown. Despite evidence that secretin at a low concentration can evoke its cellular response through the cAMP pathway (28), we assume in our experiments that the potential contribution of secretin in increased cAMP formation in salivary glands is minor or nonexistent. This assumption is based on the fact that in the pancreas, secretin at high concentrations and CCK turn on the phosphoinositide pathway $(29,30)$ as well as being supported by an overall decline of salivary TRAP secretion observed during hormonal infusion. Therefore it is possible that TRAP activity changes in human saliva are attributable to the presence of specific receptors and mechanisms in the salivary system which are similar to those responsible for pancreatic secretion. This would result in phosphatidylinositol-4,5-bisphosphate 
(PIP2) breakdown, IP3 formation, and cellular calcium mobilization leading to decreased TRAP synthesis and diminished secretion to the oral cavity. It has been shown that DAG enhances physiological events leading to increased protein secretion from parotid cells (24). Therefore, the declined inhibitory effect of secretin with caerulein on TRAP activity in saliva, 20 min subsequent to intravenous infusion, would suggest a DAG contribution to increased TRAP secretion. On the other hand, newly generated IP3 is released into the cytoplasm and releases free $\mathrm{Ca}^{2+}$ from the endoplasmic reticulum into the cytoplasm. The elevated free $\mathrm{Ca}^{2+}$ level opens a $\mathrm{Ca}^{2+}-$ dependent $\mathrm{K}^{+}$channel, and a $\mathrm{Ca}^{2+}$-dependent $\mathrm{Cl}^{-}$channel leading to increased salivary flow rate. In our study, caerulein and secretin inhibit salivary secretion. Therefore, one may assume that the mechanism responsible for this phenomenon is based on hormone-cAMP metabolism and could be explained only in part on the basis of hormone inhibition of adenylate cyclase. This inhibition can be generated by stimulation of $\alpha_{2}-$ adrenoceptors or muscarinic-cholinergic receptors. Because activation of muscarinic-cholinergic receptors results in phosphatidylinositol-4,5-bisphosphate turnover changes and elevated free $\mathrm{Ca}^{2+}$ level, the key event to fluid secretion, diminished salivary flow rate could be explained on the basis of $\alpha_{2}$-adrenoceptor stimulation.

In our experiments we cannot exclude the contribution of crevicular fluid to the TRAP activity in whole saliva. It is less probable that changes of TRAP activity could be due to direct effects of secretin and caerulein on the above mentioned extraglandular source of the enzyme.

AcP activity in whole and glandular saliva of healthy subjects without cariogenic processes is lower in comparison to the group of subjects susceptible to caries. In both groups, changes in the proportion of particular molecular forms of the AcP were also observed (31). The importance of this phenomenon in pathogenesis of caries and periodontal diseases is in need of elucidation. The osteoclasts, through their resorptive activity, present a unique property in that they form resorption pits in mineralized bone and tooth surfaces (32). Osteoclasts attached to bone demonstrate TRAP activity at the extracellular ruffled border and on the eroded bone surface (33). The immunoassay against human bone TRAP correlate with histological parameters of osteoclasts activity (34). Therefore, the observed decrease of TRAP activity resulting from secretin and caerulein stimulation may point to indirect participation of gastrointestinal hormones in activation of the cariostatic processes. Therefore, decrease of TRAP activity should be expected in patients with chronic pancreatitis in the initial phase of the disease when plasma CCK bioactivity is increased (35). It could compensate other less favorable phenomena for protective properties of saliva resulting from changeable function of salivary glands in the course of pathologic processes in the pancreas $(1,4)$. In the advanced phase of the disease, an essential decrease of plasma CCK bioactivity (35) may cause an increase in TRAP activity in saliva resulting in a disturbance of the balance between protective and aggresive factors in dental tissues and thereby intensify the cariogenic processes.
In conclusion: 1) compounds stimulating secretion of the exocrine pancreas (secretin and caerulein) have an inhibiting effect on TRAP output in whole saliva of healthy subjects; 2) the inhibitory influence of secretin and caerulein on TRAP activity points to a wider than expected participation of the digestive system in the hormonal control of biochemical processes taking place inside the oral cavity.

\section{References}

1. Kakizaki, G., Noto, N., Fujiwara, Y., Kato, E., Ishidate, T. and Saito, T. (1972) Histologic findings of the parotid gland and bicarbonate content in parotid saliva of dogs with experimentally produced pancreatitis. Tohoku J. Exp. Med. 108, 165-177

2. Kakizaki, G., Noto, N., Fujiwara, Y., Oizumi, T., Soeno, T. and Saito, T. (1972) Histologic findings and amylase content of the parotid gland of rats with recovery from acute pancreatitis. Tohoku J. Exp. Med. 108,141-153

3. Kakizaki, G., Noto, N., Onuma, T., Saito, T. and Izumi S. (1971) Experimental study on the correlation between the pancreas and parotid gland. Tohoku J. Exp. Med. 105, 223-231

4. Kakizaki, G., Saito, T., Soeno, T., Sasahara, M. and Fujiwara Y. (1976) A new diagnostic test for pancreatic disorders by examination of parotid saliva. Am. J. Gastroenterol. 65, 437-445

5. Denniss, A. R. and Young, J. A. (1978) Modification of salivary duct electrolyte transport in rat and rabbit by physalaemin, VIP, GIP and other enterohormones. Pflugers Arch. 376, 73-80

6. Gullo, L., Costa, P. L., Fontana, G. and Labo G. (1976) Investigation of exocrine pancreatic function by continuous infusion of caerulein and secretin in normal subjects and in chronic pancreatitis. Digestion 14, 97 107

7. Loguercio, C., Costato, D. and Del Vecchio Blanco, C. (1991) Inhibitory effect of caerulein on salivary secretion in man. Digestion 48, 128-133

8. Malfertheiner, P., Fußgänger, R., Minne, H. and Ditschuneit, H. (1980) Influence of gastrointestinal hormones on human salivary secretion. Horm. Metab. Res. 12, 485

9. Gomez Cerezo, J., Codoceo, R., Fernandez Calle, P., Molina, F., Tenias, J. M. and Vazquez J. J. (1991) Basal and postprandial cholecystokinin values in chronic pancreatitis with and without abdominal pain. Digestion 48, 134-140

10. Liddle, R. A., Goldfine, I. D., Rosen, M. S., Taplitz, R. A. and Williams, J. A. (1985) Cholecystokinin bioactivity in human plasma. Molecular forms, responses to feeding, and relationship to gallbladder contraction. J. Clin. Invest. 75, 1144-1152

11. Ward, K. M. and Cockayne, S. (1993) Enzymology. In Clinical chemistry concepts and applications. 1st ed., Anderson, S. C. and Cockayne, S., eds., W.B. Saunders Company, Philadelphia, 238-279 
12. Calvo, M. S., Eyre, D. R. and Gundberg, C. M. (1996) Molecular basis and clinical application of biological markers of bone turnover. Endocr. Rev. 17, 333-368

13. Atkinson, C. J., Dawes, C., Ericson, T., Fox, P. C., Gandara, B. K., Malamud, D., Mandel, I. D., Navazesh, M. and Tabak, L. A. (1993) Guidelines for saliva nomenclature and collection. Ann. N.Y. Acad. Sci. 694, xi-xii

14. Navazesh, M. (1993) Methods for collecting saliva. Ann. N.Y. Acad. Sci. 694, 72-77

15. Lowry, O. H., Rosebrough, N. J., Farr, A. L. and Randall, R.J. (1951) Protein measurement with the folin phenol reagent. J. Biol. Chem. 193, 265-275

16. Mulcahy, H., Fitzgerald, O. and McGeeney, K. F. (1972) Secretin and pancreozymin effect on salivary amylase concentration in man. Gut 13,850

17. Navazesh, M., Christensen, C. and Brightman, V. (1992) Clinical criteria for the diagnosis of salivary gland hypofunction. J. Dent. Res. 71, 1363-1369

18. Sarosiek, J., Scheurich, C. J., Marcinkiewicz, M. and McCallum, R. W. (1996) Enhancement of salivary esophagoprotection: rationale for a physiological approach to gastroesophageal reflux disease. Gastroenterology 110, 675-681

19. Agosti, A., Biasioli, S. and Bertaccini, G. (1970) Action of caerulein on pancreatic secretion in man. Pharmacol. Res. Comm. 2, 125-133

20. Kochańska, B., Witek, E. and Sibora, P.(1980) Investigations of circadian rhythmicity and temporal variability of certain parameters of mixed saliva under physiological conditions. Czas. Stomatol. 33, 491-498 (in Polish)

21. Auger, D. W. and Harrison, J. D. (1982) Ultrastructural phosphatase cytochemistry of the intercalary ducts of the parotid and submandibular salivary glands of man. Arch. Oral Biol. 27, 79-81

22. Kanagasuntheram, P. and Lim, S.C. (1978) Calciumdependent inhibition of protein synthesis in rat parotid gland. Biochem. J. 176, 23-29

23. Takuma, T., Kuyatt, B.L. and Baum, B.J. (1984) $\alpha_{1}-$ Adrenergic inhibition of protein synthesis in rat submandibular cells. Am. J. Physiol. 247, G284-G289

24. Kousvelari, E.E., Grant S.R. and Baum B.J. (1983) BAdrenergic receptor regulation of $\mathrm{N}$-linked protein glycosylation in rat parotid acinar cells. Proc. Natl. Acad. Sci. U.S.A. 80, 7146-7150
25. Mehansho, H. and Carlson, D.M. (1983) Induction of protein and glycoprotein synthesis in rat submandibular glands by isoproterenol. J. Biol. Chem. 258, 6616-6620

26. Baum, B.J., Colpo, F.T. and Filburn, C.R. (1981) Characterization and relationship to exocrine secretion of rat parotid gland cyclic AMP-dependent protein kinase. Arch. Oral Biol. 26, 333-337

27. Baum, B.J., Freiberg, J.M., Ito, H., Roth, G.S. and Filburn, C.R. (1981) B-Adrenergic regulation of protein phosphorylation and its relationship to exocrine secretion in dispersed rat parotid gland acinar cells. J. Biol. Chem. 256, 9731-9736

28. Gardner, J. D., Conlon, T. P. and Adams, T. D. (1976) Cyclic AMP in pancreatic acinar cells: effects of gastrointestinal hormones. Gastroenterology 70, 29 35

29. Trimble, E. R., Bruzzone, R., Biden, T. J. and Farese, R. V. (1986) Secretin induces rapid increases in inositol trisphosphate, cytosolic $\mathrm{Ca}^{2+}$ and diacylglycerol as well as cyclic AMP in rat pancreatic acini. Biochem. J. 239, 257-261

30. Calderon, P., Furnelle, J., and Christophe, J. (1980) Phosphatidylinositol turnover and calcium movement in the rat pancreas. Am. J. Physiol 238, G:247-254

31. Kubicz, A. and Kuczyńska-Kozłowska, S. (1979) Multiple forms of acid phosphatase from three types of human saliva. Czas. Stomatol. 32, 517-522 (in Polish)

32. Riancho, J. A., Zarrabeitia, M. T. and Gonzales-Macias, J. (1993) Interleukin-4 modulates osteoclast differentiation and inhibits the formation of resorption pits in mouse osteoclast cultures. Biochem. Biophys. Res. Commun. 196, 678-685

33. Akisaka, T., Subita, G. P., Kawaguchi, H. and Shigenaga, Y. (1989) Different tartrate sensitivity and $\mathrm{pH}$ optimum for two isoenzymes of acid phosphatase in osteoclasts. An electron-microscopic enzymecytochemical study. Cell Tissue Res. 255, 69-76

34. Allen, S. H., Nuttleman, P. R., Ketcham, C. M. and Roberts, R. M. (1989) Purification and characterization of human bone tartrate-resistant acid phosphatase. J. Bone Miner. Res. 4, 47-55

35. Koide, M., Okabayashi, Y., Hasegawa, H., Fujisawa, T., Okutani, T., Kido, Y. and Otsuki, M. (1989) Plasma cholecystokinin bioactivity in patients with chronic pancreatitis. Pancreas 4, 624 (abstract) 